\title{
THE FIFTH WORLD COMPUTER-CHESS CHAMPIONSHIP ANNOUNCED
}

\author{
ICCA Communication \\ by David Levy
}

The fifth World Computer-Chess Championship will be held in Cologne, Western Germany, from June 11 to June 15. The tournament will be a five-round, Swiss-system event, with a maximum of 32 programs. Ken Thompson will be head of the selection committee; Mike Valvo will be the Tournament Director.

Anyone interested in entering should write to David Levy (if they are in Europe) or to Ken Thompson (if they are elsewhere) with completed entry forms (see p. 270). The closing date for entries will be March 1st 1986, and successful applicants will be notified by April 1st. A certain number of "obviously acceptable" entrants will be notified in advance of April 1st.

We will also be having a session of technical papers, probably in one of the evenings. (The rounds will begin at 9 or $10 \mathrm{a} \cdot \mathrm{m}_{\bullet}$, and end at $6 \mathrm{p} \cdot \mathrm{m} \cdot$ ) We would like to have 6 papers - the theme will be "Selective Search v. Brute Force". Ideally, I would like 3 papers on each side. The call for papers is below.

\section{CALL FOR PAPERS}

There will be a technical session held during the 5th World Computer-Chess Championship, which will take place in Cologne, Western Germany, from June 11 th to 15th 1986. The theme of the technical session will be "Selective Search v. Brute Force".

Papers are invited, either in support of one side of the perennial argument, or on the relative merits of the two sides. There are no restrictive rules as to the length of the papers, but it is hoped that 6 papers will be presented during the course of the evening session ( 3 on each side). The papers will be published, either in the ICCA Journal or as a separate publication.

Authors are requested to type their submissions, in English on A4 paper with a $2.5 \mathrm{~cm}$ left hand margin. The typing should be single spaced. Papers should be sent to:

David Levy

11 Loudoun Road

London NW8 OLP

ENGLAND

to arrive not later than March 31st, 1986.

Papers submitted for this event should be accompanied by a letter from the author certifying that he/she agrees to the publication, on a non-profit making basis, by or at the discretion of the ICCA, without payment to the author.

In order to assist with editing, it would be most helpful if authors could prepare their papers on a IBM PC, using Wordstar (not Wordstar 2000). 